\title{
FAKTOR-FAKTOR YANG BERPENGARUH PADA PRODUKSI HASIL LAUT DI KABUPATEN LAMONGAN
}

\author{
Bayu Sentosa \\ Sayekti Suindyah Dwiningwarni \\ Desy Indar Rohmawati N \\ Universitas Islam Darul 'Ulum Lamongan \\ bayu.sentosa89@gmail.com \\ sayekti.undar67@gmail.com \\ Indar.desy14@yahoo.com
}

\begin{abstract}
This research was carried out at PT. Starfood International in Lamongan District which is located in Deandles Street, Paciran Subdistrict, is a rambling company in the field of fish processing. PT. starfood international was established in 2009. the problem formulation of this research is the factors that influence the realization of fish processing production production at PT. starfood international in increasing production. Analysis of quantitative data is a model to measure what factors affect fish processing in PT. starfood international. in this study using multiple linear regression, the results of research and discussion of problem analysis at PT. starfood international is a factor of raw materials, the selling price of production, the number of machines simultaneously or together have a significant influence on production results, this is based on the results of the F test study which shows $F$ count is greater than $F$ table at a significant level 0.05 ie $F$ count (64.923)> F table value (19.00). based on the results of the study all variables affect the realization of production.
\end{abstract}

Keywords: raw material, production selling price, number of production machines at PT. starfood international.

\begin{abstract}
Abstrak: Penelitian ini di laksanakan di pt. starfood internasional di kabupaten lamongan yan berlokasi di jalan deandles kecamatan paciran merupakan perusahaan yan bererak di bidang produksi penolahan ikan. PT. starfood internasional berdiri pada tahun 2009. rumusan masalah dari penelitian ini adalah faktor-faktor yang mempengaruhi realisasi produksi produksi pengolahan ikan pada PT. starfood internasional dalam meningkatkan produksi. analisis data kuanitatif yaitu dengan model untuk mengukur faktor-faktor apa saja yan mempengaruhi pengolahan ikan di PT. starfood internasional. dalam penelitian Sini menggunakan regrsi linier berganda, hasil penelitian dan pembahasan dari analisa permasalahan di PT. starfood internasional adalah faktor bahan baku, harga jual produksi, jumlah mesin secara simultan atau secara bersama-sama mempunyai pengaruh yan signifikan terhadap hasil produksi, hal ini berdasarkan dengan hasil penelitian uji $\mathrm{F}$ yang menunjukkan $\mathrm{F}$ hitung lebih besar dari pada $\mathrm{F}$ tabel pada taraf level signifikan 0,05 yakni $\mathrm{F}$ hitung $(64,923)>$ nilai $\mathrm{F}$ tabel $(19,00)$. berdasarkan hasil penelitian semua variabel mempengaruhi realisasi produksi.
\end{abstract}

Kata kunci: bahan baku, harga jual produksi, jumlah mesin produksi di PT. starfood internasional.

\section{PENDAHULUAN}

Sebuah strategi tidak boleh bereaksi secara reaktif terhadap perubahan lingkungan, tetapi secara proaktif membentuk kesuksesan jangka panjang perusahaan meskipun mengubah kondisi lingkungan dan umum dan dengan demikian memastikan kelangsungan 
Humanis Vol 11 No 2

hidupnya (Bea FX dan haas j, 2009:29; zapfel G, 2000:30). Untuk kesuksesan jangka panjang,membangun, mempertahankan dan mempertahankan keunggulan kompetitif dapat didefinisikan sebagai tujuan penting (zapfel G, 2000:30; friedli T, 2006:51; teece DJ, at al 1997:509-533).

Berdasarkan arah strategis perusahaan yang jelas ini, derivasi dari strategi manufaktur terjadi (Zapfel G, 2000:30). Oleh karena itu, produksi merupakan faktor kompetitif strategis di mana perusahaan dapat membedakan diri dari pesaing mereka (Dombrowski U, 2015:9-14). Produksi ini merupakan "seluruh langkah ekonomi, teknologi dan organisasi yang terkait secara langsung terhubung dengan pemrosesan / permesinan material, yaitu semua fungsi dan kegiatan yang secara langsung berkontribusi pada pembuatan barang (Cirp, 2004:18)yang berusaha secara tepat memenuhi preferensi produk pribadi pelanggan untuk membedakan diri mereka sendiri dari pesaing. Oleh karena itu, individualisasi mensyaratkan bahwa produk yang ditawarkan dan pemenuhan fungsional mereka sesuai dengan kebutuhan individu pembeli (pillerFT2006:114). Selain kustomisasi produk, target logistik yang berorientasi eksternal sangat penting untuk strategi diferensiasi dari perspektif produksi (zapfel G, 2000:30; porter MZ, 1998:3581; nyhuis p dan wiendahl H-P, 2012:1227; wiendahl H-P, at al 2006:467).

Faktor-faktor yang mempengaruhi produksi terdiri dari 6 yaitu Jumlah mesin, modal, permintaan, harga, bahan baku dan tenaga kerja. Pada prinsipnya, aktiva tetap dapat dikurangi jika volume produksi yang dibutuhkan dapat diproduksi dengan jumlah yang lebih kecil dari alat-alat produksi (Hungenberg $\mathrm{H}$, at al 2006:3581; Topfer A, 2007:792; Schuh G, 2012:108-111). Intensitas penggunaan sarana produksi yang ada digambarkan oleh pemanfaatan (Jodlbauer H, 2008:2140). Namun, secara intensif atau dimanfaatkan secara maksimal sarana individu produksi sering menyebabkan kemacetan, sehingga sarana produksi lainnya, karena waktu tunggu, memiliki pemanfaatan yang lebih rendah (Becker T, 2008:56).

Berdasarkan hasil pertama ini, Publikasi menunjukkan bahwa Strategi Kompetitif Generik dapat atau harus dikejar oleh perusahaan manufaktur pada saat yang sama untuk menjadi kompetitif. Untuk memungkinkan produk / pasar orientasi strategis tertentu dari produksi, faktor-faktor keberhasilan strategi kompetitif generik yang berasal dalam artikel ini. Ini adalah pemanfaatan proses (1), proses kesamaan (2) serta individualisasi produk (3) dan waktu pengiriman (4). Berdasarkan faktor-faktor keberhasilan tersebut, posisi strategis dari produksi dalam pemimpin biaya dan strategi diferensiasi dapat dibuat. Selain ini, deskripsi matematika empat faktor keberhasilan tersebut digambarkan.

Hal ini memungkinkan produksi untuk mengukur posisi strategis mereka, yang memungkinkan derivasi dari pasar atau langkah-langkah strategis khusus produk (Dombrowski. Krenkel \&wullbrandt, 2018:1200-1201).Hasil yang diperoleh atas dasar penerapan pembandingan dan hasil analisis dari 281 lelang di negara-negara UE terpilih disajikan dalam kontribusi yang diserahkan (Corejova. Andriskova \& $\mathrm{Al}$ kassiri, 2017:257). Hasilnya menunjukkan reaktivasi kesalahan yang lebih disukai untuk kesalahan pencelupan yang tajam, koefisien Biot-Willis yang besar, beban overburden yang tidak homogen, ketebalan reservoir yang besar, posisi reservoir yang dangkal dan jarak pendek dari lapisan garam ke reservoir. Pada bagian ketiga kami menyelidiki efek kesalahan sesar dan membuang kesalahan 
yang dimuat oleh tiga skenario deplesi dalam pengaturan intra-graben terkotak.

Pemuatan kesalahan maksimum diperoleh untuk kasus kesalahan patahan setengah dari ketebalan reservoir dan produksi secara eksklusif dari blok footwall. Temuan utama adalah reservoir dan produksi secara eksklusif dari blok footwall. Temuan utama adalah reaktivasi yang disukai dari kesalahan pencelupan yang tajam $\left(>60^{\circ}\right)$ yang disebabkan oleh kontribusi dominan pemadatan reservoir terhadap pembebanan sesar. Pemadatanloading merupakan perbedaan utama untuk kegempaan didorong oleh tektonik medan jauh didominasi oleh ketegangan horisontal, yang kesalahan dengan sudut kemiringan sekitar 60॰ diperkirakan menguntungkan untuk reaktivasi (Haug $\mathrm{C}$. Nuhter A. Henk A, 2018:1)

Penelitian ini dilakukan dengan alasan melanjutkan penelitianDombrowski, Krenkel \& wullbrandt, 2018yang menelititentangStrategic Positioning of Production within the Generic Competitive Strategisfaktor-faktor yang mempengaruhi produksi dan peranan perencanaan dan pengawasan produksi sangat menentukan keberhasilan pencapaian target yang telah di tetapkan oleh perusahaan. Oleh karena itu peneliti akan melakukan penelitian dengan judul "Analisis Faktor-Faktor yang Mempengaruhi Produksi Hasil Laut di PT. Starfood Internasional Lamongan”. Penelitian ini bertujuan untuk mengetahui faktor-faktor yang berpengaruh signifikan terhadap produksi hasil laut di PT. Starfood Internasional dalam meningkatkan hasil produksi.dan mengetahui faktor yang dominan yang di hadapi oleh PT. Starfood Internasional dalam upaya meningkatkan output produksi.

Hasil penelitian ini diharpakan akan dapat dijadikan bahan referensi guna pengembangan ilmu pengetahuan
Humanis Vol 11 No 2

khususnya pada bidang manajamen produksi. Bagi Perusahaan Hasil penelitian ini diharapkan dapat digunakan sebagai bahan pertimbangan bagi perusahaan dalam pengambilan keputusan yang berkaitan dengan manajemen produksi guna peningkatan kualitas produksi. Bagi peneliti lain Hasil penelitian ini dapat dijadikan referensi dalam melakukan penelitian yang berkaitan dengan produksi.

\section{Kerangka Teoristis \\ Pengertian produksi}

Teori produksi adalah studi tentang produksi atau proses ekonomi untuk mengubah faktor produksi (input) menjadi hasil produksi (output). Proses menggunakan sumber daya untuk menciptakan barang atau jasa yang sesuai untuk digunakan (erlina, 2015:43). produksi merupakan faktor kompetitif strategis di mana perusahaan dapat membedakan diri dari pesaing mereka (Dombrowski U, 2015:9-14).

\section{Bahan Baku}

Bahan baku adalah barang-barang yang digunakan dalam proses produksi yang dapat mudah dan langsung diidentifikasi dengan barang atau produk jadi. Berdasarkan pengertian secara umum, perbedaan arti kata antara bahan baku dan bahan mentah dapat mempunyai arti sebagai sebuah bahan dasar yang berada di berbagai tempat, yang mana bahan tersebut dapat digunakan untuk diolah dengan suatu proses tertentu ke dalam bentuk lain yang berbeda wujud dari bentuk aslinya (Soemarso, 2005:271). bahan baku adalah bahan yang membentuk bagian besar produk jadi, bahan baku yang diolah dalam perusahaan manufaktur dapat diperoleh dari pembelian lokal, impor atau hasil pengolahan sendiri. Jenis-jenis bahan baku terbagi menjadi dua, antara lain yaitu bahan baku langsung dan tidak langsung (Kholmi, 2005;29). 
1. Bahan baku langsung atau direct material adalah semua bahan baku yang merupakan bagian daripada barang jadi yang di hasilkan. Biaya yang di keluarkan untuk membeli bahan baku langsung ini mempunyai hubungan yang erat dan sebanding dengan jumlah barang jadi yang di hasilkan.

2. Bahan baku tidak langsung atau disebut juga dengan indirect material, adalah bahan baku yang ikut berperan dalam proses produksi tetapi tidak secara langsung tampak pada barang jadi yang di hasilkan.

\section{Harga}

Menurut Kotler (2001: 439), harga adalah jangka waktu nilai yang ditukar oleh konsumen untuk review memperoleh suatu produk, atau sejumlah uang yang dibebankan untukreview konsumen guna get barang atau jasa.Harga Sangat berpengaruh pada citra produk dan kelangsungan produk dipasaran.jika harga suatu produk terlalu murah atau terlalu mahal, hal tersebut dapat berpengaruhburuk untuk review suatu produk. Oleh karena itu, hearts menetapkan harga suatu produk perlu adanya penetapan tujuan dan mengembangkan suatu struktur penetapan harga yang tepat (Putong, 2013).

\section{Jumlah Mesin}

Mesin adalah suatu peralatan yangdigerakkan oleh sesuatu kekuatan/tenaga yang dipergunakan untuk membantumanusia dalam mengerjakan produk atau bagian-bagian produk tertentu (Assauri, 2004 : 79). Ada juga yang beranggapan bahwa yang dimaksud dengan mesin adalah suatu peralatan yang digerakkan oleh suatu kekuatan/tenaga yang dipergunakan untuk membantu manusia dalam mengerjakan produk atau bagian-bagian produk tertentu. ada dua macam jenis-jenis mesin yang dapat
Humanis Vol 11 No 2

digunakan didalam suatuperusahaan (Assauri, 2004 : 79)

Menurut Assauri (2004:79) mesinmesin dapat dibagi menjadi dua macam yaituMesin yang bersifat umum (general purpose machine) dan Mesin-mesin yang bersifat khusus (special purpose machine)

Mesin yang bersifat umum ini merupakan suatu jenis mesin yang dibuatuntuk mengerjakan pekerjaan tertentu untuk berbagai jenis produk. mesin-mesin seperti ini biasanya digunakan oleh perusahaan yang memproduksi jenis barang (produk) dalam jumlah kecil.

Adapun ciri-ciri mesin yang bersifat umum adalah sebagai berikut :

a. Mesin-mesin ini biasanya dibuat dengan bentuk standar dan selalu atas dasar untuk pasar dan diproduksi dalam jumlah yang besar.

b. Mesin-mesin yang digunakan dapat menghasilkan beberapa macam produksi.

c. Dibutuhkan adanya tenaga kerja yang terdidik dan berpengalaman.

d. Mesin-mesin ini biasanya tidak otomatis, dan memerlukan banyak tenaga kerja dan biaya mahal.

e. Mesin-mesin seperti ini biasanya tidak mudah ditinggalkan banyak tenaga kerja dan biaya mahal.

Mesin-mesin yang bersifat khusus (special purpose machine)

Mesin yang bersifat khusus ini merupakan mesin-mesin yang dirancang dandibuat untuk mengerjakan suatu atau berbagai jenis kegiatan yang sama. Mesinmesin seperti ini biasanya ditemui pada perusahaan-perusahaan yangmengadakan produksi massa.

adapun ciri-ciri mesin yang bersifat khusus adalah sebagai berikut:

a. Mesin-mesin ini dibuat berdasarkan pesanan dalam jumlah yang kecil.

b. Mesin-mesin yang bersifat khusus ini biasanya agak otomatis dan dipergunakan dalam pabrik yang 
Humanis Vol 11 No 2

menghasilkan produk dalam jumlahyang besar.

c. Dibutuhkan tenaga kerja yang lebih sedikit

d. Biaya maintenance lebih mahal, dan diperlukan tenaga kerja ahli yangkhusus.

e. Biaya produksi perunit lebih murah.

f. Mesin-mesin ini tidak dapat dipergunakan untuk menghadapi perubahandari produk yang diminta pelanggan.

g. Mesin-mesin ini mudah ketinggalan zaman.

Oleh karena itu dalam penentuan mesin-mesin untuk kegiatan produksisangat diperlukan. dari hal diatas dalam penentuan mesin untuk proses produksiair minum yang dilakukan perusahaan air minum adalah menggunakan mesinyang bersifat khusus.

\section{Penelitian Terdahulu}

Hasil penelitian Yanli Li, Lijun Li (2012) bahwa perkembangan teori faktorfaktor produksi adalah proses perluasan manusia dan menyusutnya faktor EM, itu adalah pentingnya kehilangan yang EM berpartisipasi dalam pembentukan nilai produk

Hasil penelitian Stephen A Northey, Cristina Madrid L opez, Nawshad Haque, Gavin M. Mudd (2018) menunjukkan bahwa karakterisasi dampak menggunakan rata-rata nasional ' Indeks air Stres '(WSI) akan melebihlebihkan dampak penggunaan air untuk $67 \%$ dari operasi penambangan bila dibandingkan dengan penilaian menggunakannilai WSI DAS.

Hasil penelitian Uwe Dombrowski, philip krenkel, Jonas wullbrandt (2018) menunjukkan bahwa Strategi Kompetitif Generik dapat atau harus dikejar oleh perusahaan manufaktur pada saat yang sama untuk menjadi kompetitif. Untuk memungkinkan produk / pasar orientasi strategis tertentu dari produksi, faktor-

faktor keberhasilan strategi kompetitif generik yang berasal dalam artikel ini. Ini adalah pemanfaatan proses (1), proses kesamaan (2) serta individualisasi produk (3).

\section{METODE PENELITIAN}

Pendekatan ini digunakan pendekatan longitudinal. Penelitian ini menggunakan data yang di ambil adalah data kuantitatif dari tahun 2012-2017. Metode kuantitatif adalah metode penelitian yang berdasarkan pada filsafat positivisme, digununakan untuk meneliti pada populasi atau sampel tertentu, pengumpulan data menggunakan instrumen penelitian, analisis data bersifat kuantitatif/statistik, dengan tujuan untuk menguji hipotesis yang telah di tetapkan (Sugiyono, 2016:8)

\section{Tempat Penelitian}

Dalam melakukan penelitian ini, penulis menetapkan lokasi penelitian di PT. STARFOOD INTERNASIONAL di paciranLamongan

\section{Objek Penelitian}

Objek penelitian ini adalah modal, jumlah mesin, bahan baku, harga, permintaan, tenaga kerja di produksidi PT.STARFOOD INTERNASIONAL paciran lamongan.

Populasi, Sampel dan Teknik Pengambilan Sampel

Populasi adalah wilayah generalisasi yang terdiri atas: obyek/subyek yang mempunyai kualitas dan karakteristik tertentu yang ditetapkan oleh peneliti untuk dipelajari dan kemudian ditarik kesimpulanya (Sugiyono, 2016:80). Sampel adalah bagian dari jumlah dan karakteristik yangdimiliki oleh populasi tersebut (Sugiyono, 2016:81). Teknik pengambilansampel pada penelitian ini adalah probability sampling. Probability sampling adalah teknik pengambilan sampel yang memberikan peluang yang sama bagi setiap unsur (anggota ) populasi 
Humanis Vol 11 No 2

untuk dipilih menjadi anggota sampel. Sedangkan non probability sampling adalah teknik pengambilan sampel yang tidak memberi peluang/kesempatan sama bagi setiap unsur atau anggota populasi untuk dipilih menjadi sampel. (Sugiyono, $2016: 82-84$ )

\section{VARIABEL PENELITIAN \\ Variabel Independen (bebas)}

Variabel independen di sebut sebagai variabel stimulus, prediktor, antecedent. Dalam bahasa indonesia sering di sebut sebagai variabel babas. Variabel bebas marupakan variabel yang mempengaruhi atau yang menjadi sebab perubahannya atau timbulnya variabel dependen (terikat) (sugiono,2016:39).

\section{Variabel Dependen (terikat)}

Variabel dependen sering disebut variabel output, kriteria, konsekuen. Dalam bahasa indonesia sering disebut sebagai variabel terikat. Vvariabel terikat merupakan variabel yang dipengaruhi atau yang menjadi akibat, karena adanya variabel bebas (sugiono, 2016:39).

\section{Teknik Pengumpulan Data Wawancara}

Merupakan teknik pengumpulan data yang berupa pertanyaan-pertanyaan yang ditanyakan kepada responden. Baik dengan cara wawancara terstruktur maupun wawancara tidak terstruktur (Sugiyono, 137-142)

\section{Observasi}

Observasi Merupakan suatu proses yang kompleks, suatu proses yang tersusun dari berbagai proses biologis dan psikis. Dua di antaranya yang terpenting adalah proses-proses pengamatan dan ingatan (Sugiyono, 2016:145 dalam Sutrisno Hadi 1986).

\section{Metode Analisis Data}

\section{Metode regresi linier berganda}

Penelitian ini menggunakan teknik analisis regresi linier berganda ( cobbdouglas) diolah dengan menggunakan progam SPSS (statistica packages for social science). Bentuk umum regresi linear beganda adalah sebagai berikut:

$\operatorname{Ln} Y=\operatorname{Ln} \beta_{o}+\beta 1 \operatorname{Ln} x 1+\beta 2 \operatorname{Ln} X 2+\beta 3$ $\mathrm{LnX} 3+$

Keterangan:

$\mathrm{Y}=$ Faktor-faktor yang mempengaruhi produksi

$\beta_{\mathrm{o}}=$ Konstanta

$\mathrm{X} 1=$ Bahan baku

$\mathrm{X} 2=$ Harga

X3= Jumlah mesin

\section{Uji asumsi}

\section{Uji Multikolinearitas}

Uji Multikolinearitas adalah menguji apakah pada model regresi yang dibuat di temukan adanya korelasi antar variabel bebas. Uji ini dilakukan dengan melihat nilai tolerance dan variance inflation factor (VIF). Jika hasil nilai tolerance $>0,10$ atau VIF $<10$ maka tidak terjadi multikolinearitas dalam model (ghozali, 2005:105).

\section{Uji Heteroskedastisitas}

Uji Heteroskedastisitas memiliki tujuan untuk menguji apakah model regrasi linier kesalahan pengganggu (e) mempunyai varians yang sama atau tidak. Uji heteroskedastisitas dapat diketahui dari nilai sig korelasi rank spearman antara masing-masing variabel bebas dengan residualnya. Jika nilai signifikan > $(0,05)$ maka tidak terdapat heteroskedastisitas, dan sebaliknya jika < $(0,05)$ maka terdapat heteroskedastisitas (utama, 2014:107).

\section{Uji Autokorelasi}

Uji Autokorelasi merupakan korelasi antara variabel gangguan satu dengan variabel gangguan lainnya. Akibat adanya autokorelasi adalah parameter yang diestemasikan menjadi bias dan variannya tidak minimum, sehingga tidak efisien. Untuk menguji ada tidaknya autokorelasi digunakan dengan uji Durbin Watson (DW-test).

Uji hipotesis 


\section{Hipotesis 1}

Pengujian ini di lakukan untuk mengetahui apakah semua variabel bebas secara bersama-sama dapat berpengaruh terhadap variabel dependen.

Menentukan formulasi hipotesis:

Ho : $\beta_{1}=0$ yaitu tidak ada pengaruh antara variabel bebas $(\mathrm{x})$ dengan variabel terikat (y).

Ho : $\beta_{1} \neq 0$ yaitu ada pengaruh antara variabel bebas (x) dengan variabel terikat (y).

\section{HASIL PENELITIAN DAN PEMBAHASAN \\ Gambaran Umum Tempat Penelitian \\ Sejarah Berdirinya PT. Starfood International Lamongan \\ PT. Starfood International} Lamongan (SFI) adalah bagian dari kelompok usaha PT. Prima Star International (Kelola Mina Laut Grup) yang didirikan di Gresik berdasarkan akta No.28 tanggal 18 April 2008 dari notaris Wachid Hasyim S.H Surabaya dengan pengesahan dari HAM No.AHU25263.AH.01.01. Kantor pusat perusahaan beralamat di Jl. KIG Raya Selatan Kav.C-7 Kawasan Industri Gresik, Jawa Timur. Proyek pendirian PT. Starfood International dimulai pada awal bulan Oktober 2008 dan resmi beroperasi pada tanggal 1 Oktober 2009 yang diikuti dengan awal proses produksi pada tanggal 26 Oktober 2009.

PT. Starfood International mempunyai berbagai macam produk yaitu surimi, frozen fish dan frozen cephalopoda serta tepung ikan. Produk frozen fish terdiri dari ikan swangi (P. tayenus), ikan kurisi (Nemipterus japonicus), ikan gulamah (Nibea albiflora), ikan ayamayam (Abalistes stellaris), ikan puntung damar (Siliago siliama) dan tonang (Plectaster decanus). Produk Frozen cephalopoda terdiri dari bekutak (Sephia sp.) dan cumi-cumi (Loligosp.). Produk tepung ikan berasal dari limbah padat
Humanis Vol 11 No 2

frozen fish dan surimi. Produk-produk tersebut dipasarkan skala ekspor ke negara Taiwan, Vietnam, Singapura dan China.

\section{Letak Geografis}

Lokasi PT. Starfood International terletak di Jalan Raya Deandles Km.76 Desa Kandang Semangkon, Kecamatan Paciran, Kabupaten Lamongan, Jawa Timur secara geografis pabrik ini terletak pada garis lintang $6.87128^{\circ} \mathrm{LS}$ dan $112.31538^{\circ} \mathrm{BT}$ dengan batas-batas wilayah sebagai berikut:

- Sebelah Utara : Laut Jawa

- Sebelah Selatan : Jalan Raya Tuban Surabaya

- Sebelah Timur : Tanah milik H. Samiin

- Sebelah Barat : Tanah milik H. Muhlis

Kondisi lingkungan sekitar PT. Starfood International ini cukup dinamis. Lokasi ini memiliki tingkat mobilitas yang sedang, karena daerah ini sedang berkembang. Jarak lokasi dengan ibu kota kabupaten $\pm 5 \mathrm{~km}$. Kegiatan mata pencaharian di lingkungan sekitar pabrik adalah nelayan dan pembudidayaan udang.

\section{Deskripsi Variabel}

Dari hasil penelitian yang dilakukan di PT. Starfood Intenational Lamongan dapat diketahui deskripsi variabel sebagai berikut:

\section{Hasil Produksi}

Maksud dari ditetapkannya rencana dalam berproduksi adalah untuk memberikan gambaran yang akan memberikan arah agar yang direncanakan itu

benar-benar sesuai dengan maksud dalam produksi, sehingga nantinya akan dapat tercapai sesuai dengan tujuan perusahaaan. Hingga saat ini PT. Starfood Intenational Lamongan belum mampu untuk mencapai hasil produksi yang direncanakan setiap tahunnya. Untuk lebih jelasnya dapat 
dilihat pada tabel 4.1 mengenai rencana dan realisasi produksi:

Tabel 4.1 Target Produksi dan Realisasi Produksi Hasil Laut PT. Starfood International Tahun 2013 - 2017

\begin{tabular}{|c|c|c|c|}
\hline Tahun & Target Produksi & Realisasi Produksi & Presentase (\%) \\
\hline 2013 & 16.000 & 10.643 & $67 \%$ \\
\hline 2014 & 16.000 & 13.526 & $85 \%$ \\
\hline 2015 & 14.000 & 8.547 & $61 \%$ \\
\hline 2016 & 10.000 & 6.474 & $65 \%$ \\
\hline 2017 & 8.000 & 4.375 & $55 \%$ \\
\hline
\end{tabular}

Sumber: PT. Starfood International Lamongan

Dari tabel 4.1 dapat dilihat bahwa rencana produksi tiap tahunnya selalu mengalami perubahan berdasarkan kebijakan yang telah ditetapkan perusahaan.

Produksi Hasil Laut selama lima tahun terakhir berfluktuasi dan menunjukkan bahwa perusahaan belum mampu memenuhi target produksi yang telah ditetapkan.

Pada tahun 2013 rencana produksi sebesar 16.000 ton, sedangkan yang dapat dicapai 10.643 ton atau sekitar 67\%. Pada tahun 2014 rencana produksi sebesar 16.000 ton, sedangkan yang dapat dicapai 14.000 ton atau sekitar $85 \%$. Selanjutnya pada tahun 2015 rencana produksi sebesar 14.000 ton, sedangkan yang dapat dicapai 8.547 ton atau sekitar terdapat $61 \%$. Pada tahun 2016 rencana produksi sebesar 10.000 ton, sedangkan yang dapat dicapai 6.474 ton atau sekitar 65\%. Pada tahun 2017 rencana produksi sebesar 8.000, sedangkan yang dapat dicapai 4.375 atau $55 \%$.

\section{Bahan Baku}

Pengadaan bahan baku merupakaan suatu bagian terpenting dalam suatu proses produksi pada suatu perusahaan, tanpa adanya bahan baku proses produksi tidak akan berjalan tanpa adanya bahan baku yang harus diproses menjadi barang jadi atau setengah jadi, karena setiap perusahaan yang menghasilkan produk akan

membutuhkan bahan baku.

Apabila suatu perusahaan dalam melakukan kegiatan operasi mengalami kekurangan bahan baku, maka kemungkinan perusahaan tersebut akan mengalami kerugian yang disebabkan oleh persediaan bahan baku yang tidak memadai, mengingat macetnya persediaan bahan baku akan menghentikan kegiatan produksi. Oleh karena itu, perusahaan harus dapat membuat/menentukan perencanaan pemakaian bahan baku selama satu periode. Perkiraan kebutuhan bahan baku dapat diketahui dari rencana produksi perusahaan pada periode bersamaan.

Untuk lebih jelasnya mengenai rencana dan realisasi bahan baku pada PT. Starfood International Lamongan dari tahun 2013 sampai 2017 dapat dilihat pada tabel 4.2 dibawah ini:

Tabel 4.2 Rencana, Realisasi Bahan Baku dan Persediaan Bahan Baku Produksi Hasil Laut PT. Starfood International Lamongan Tahun 2013 - 2017

\begin{tabular}{|c|c|c|c|}
\hline Tahun & $\begin{array}{c}\text { Kebutuhan Bahan } \\
\text { Baku (Ton) }\end{array}$ & $\begin{array}{c}\text { Persedian Bahan } \\
\text { Baku (Ton) }\end{array}$ & $\begin{array}{c}\text { Tingkat Pencapaian } \\
(\mathbf{\%})\end{array}$ \\
\hline 2013 & 2.000 ton & 1.373 ton & $69 \%$ \\
\hline 2014 & 2.000 ton & 1.427 ton & $71 \%$ \\
\hline 2015 & 3.500 ton & 2.900 ton & $83 \%$ \\
\hline
\end{tabular}


Humanis Vol 11 No 2

\begin{tabular}{|l|l|l|l|}
\hline 2016 & 3.500 ton & 1.200 ton & $34 \%$ \\
\hline 2017 & 3.500 ton & 1.000 ton & $29 \%$ \\
\hline
\end{tabular}

Sumber: PT. Starfood International Lamongan

Dari tabel diatas dapat dilihat perkembangan jumlah bahan baku selama lima tahun terahir. Dimana perusahaan belum mampu memenuhi target kebutuhan bahan baku yang diperlukan dalam memproduksi hasil laut tersebut.

Data-data bahan baku diatas menunjukkan bahwa perusahaan mengalami

kekurangan bahan baku yang cukup besar dalam beberapa tahun terakhir. Untuk tahun 2013, perusahaan menargetkan kebutuhan bahan baku sebesar 2.000 ton, tetapi terealisasinya hanya sebesar 1.373 ton atau sebesar 69\%. Pada tahun 2014, perusahaan menargetkan kebutuhan bahan baku sebesar 2.000 ton, dan dapat terealisasi sebesar 1.427 ton atau sebesar $71 \%$. Untuk tahun 2015, perusahaan menargetkan kebutuhan bahan baku sebesar 3.500, tetapi terealisasi sebesar 2.900 ton atau sebesar $83 \%$. Tahun 2016, perusahaan menargetkan kebutuhan bahan baku sebesar 3.500 ton, terealisasi sebesar
1.200 ton atau sebesar 34\%. Pada tahun 2017, perusahaan menargetkan 3.500 ton, tetapi terealisasi sebesar 1.000 ton atau sebesar 33\%.

\section{Harga Jual}

Harga jual adalah sejumlah kompensasi (uang ataupun barang) yang dibutuhkan untuk mendapatkan sejumlah kombinasi barang atau jasa. Perusahaan selalu menetapkan harga produknya dengan harapan produk tersebut laku terjual dan boleh memperoleh laba yang maksimal. Jadi menurut perusahaan penetapan harga jual merupakan hal yang sangat penting, karena penetapan harga jual adalah suatu keputusan atau strategi perusahaan dalam menarik minat konsumen dan mempertahankan loyalitas pelanggan.

Berikut adalah tabel harga jual produk dari pada PT. Starfood International Lamongan dari tahun 2013 sampai 2017:

Tabel 4.3 Daftar Harga Jual Produksi Hasil Laut PT. Starfood International Lamongan Tahun 2013 - 2017

\begin{tabular}{|l|l|l|}
\hline Tahun & Harga (USD/kg) & Harga (Rupiah/kg) \\
\hline 2013 & 2,7 & 29.430 \\
\hline 2014 & 2,7 & 26.325 \\
\hline 2015 & 2,8 & 37.520 \\
\hline 2016 & 2,9 & 38.860 \\
\hline 2017 & 3,05 & 40.905 \\
\hline
\end{tabular}

Sumber: PT. Starfood International Lamongan

Berdasarkan tabel di atas menggambarkan bahwa harga judal produk PT. Starfood International Lamongan mengalami peningkatan dari tahun 2014 hingga tahun 2017. Harga jual yang ditentukan secara baku dengan nilai mata uang dollar amerika (USD) karena hasil produksinya diekspor ke luar negeri. Jumlah Mesin

Dalam pelaksanaan proses produksi, keberadaan mesin sebagai alat bantu untuk menjalankan proses produksi sangat 
dibutuhkan. Dengan adanya adanya mesin akan dapat membantu kelancaran proses produksi.

Penggunaan mesin dalam suatu proses produksi bermula dari waktu manusia yang tidak hanya memproduksi hanya memenuhi kebutuhan sendiri, akan tetapi untuk memenuhi kebutuhan orang lain. Keadaan ini mengharuskan manusia memproduksi suatu produk dalam jumlah yang banyak, maka untuk memenuhi tuntutan yang demikian, hampir semua jenis produk memerlukan bantuan mesin agar dapat mengolahnya sehingga dapat menghasilkan produk yang diinginkan serta sesuai dengan standar yang telah ditetapkan. Penggunaan mesin dan peralatan proses produksi, tergantung kepada produk apa yang akan diproduksi, begitu juga halnya dengan jenis mesin dan peralatan produksi yang digunakan dalam suatu proses pada tiap-tiap perusahaan tidaklah sama. Masalah yang selalu diperhatikan oleh suatu perusahaan dalam penggunaan mesin dan peralatan produksinya adalah bagaimana dangan penggunaan mesin dan peralatan produksinya tersebut agar berproduksi secara efisien dan efektif.

Mengenai jumlah mesin yang dimiliki oleh PT. Starfood International Lamongan dapat dilihat pada tabel 4.3 berikut:

Tabel 4.4 Jumlah Mesin Pada PT. Starfood International Lamongan

Tahun 2013-2017

\begin{tabular}{|c|l|c|c|c|c|c|}
\hline \multirow{2}{*}{ No } & Nama Peralatan & \multicolumn{5}{|c|}{ Tingkat Penambahan Peralatan per/unit } \\
\cline { 2 - 7 } & 2013 & 2014 & 2015 & 2016 & 2017 \\
\hline 1 & $\begin{array}{l}\text { Pemotongan } \\
\text { kepala ikan }\end{array}$ & 10 & 9 & 9 & 9 & 9 \\
\hline 2 & $\begin{array}{l}\text { Alat pemisah } \\
\text { daging ikan } \\
\text { dengan tulang }\end{array}$ & 1 & 1 & 1 & 1 & 1 \\
\hline 3 & $\begin{array}{l}\text { Alat } \\
\text { pengepakan }\end{array}$ & 4 & 4 & 4 & 4 & 4 \\
\hline
\end{tabular}

Sumber: PT. Starfood International Lamongan

Berdasarkan data pada tabel di atas menunjukkan bahwa jumlah mesin yang dimiliki dari tahun ke tahun realtif tetap. Hal tersebut menunjukkan bahwa perusahaan sangat memperhatikan perawatan mesin penunjang produksinya.

Dalam hal mengadakan perawatan terhadap mesin-mesin yang digunakan dalam proses produksi, diperoleh informasi dari pihak perusahaan bahwa perusahaan melakukan perawatan dan reparasi terhadap mesin-mesin produksinya apabila terjadi kerusakan. Disamping itu, perusahaan juga melakukan perawatan secara berkala terhadap mesin-mesin produksinya dengan mengadakan reparasi. Disini jelas bahwa perusahaan telah berusaha menjalankan preventif maintenance. Oleh karena itu, sudah selayaknya menjadi pertimbangan bagi pihak perusahaan demi kelancaran proses produksi. Jadi dengan tingkat kerusakan yang akibatnya akan menganggu kelancaran proses produksi dan hasil produksi.

\section{Hasil Pengujian Data}

Dalam pembahasan hasil penelitian ini maka penulis menggunakan formula atau analisa data dengan menggunakan regresi linier berganda. Setelah dilakukan 
tabulasi terhadap hasil perhitungan masing-masing variabel maka data-data tersebut dimasukkan atau diproses dengan menggunakan program SPSS versi 17.00.

\section{Pengujian Asumsi Klasik}

Untuk mengetahui apakah hasil estimasi regresi yang dilakukan betul betul

terbebas dari adanya gejala Heteroskadestisitas, Multikolinearitas, dan
Autokorelasi, perlu dilakukan pengujian yang disebut Uji asumsi Klasik.

\section{Uji Normalitas}

Uji normalitas distribusi data dengan menguji residual-residual dimaksud untuk melihat apakah data terdistribusi secara normal. Untuk uji normalitas ini menggunakan uji OneSample Kolmogorov-Smirnov. Berikut adalah hasil pengujian normalitas data hasil penelitia:

Tabel 4.5Hasil Pengujian Normalitas

One-Sample Kolmogorov-Smirnov Test

\begin{tabular}{|c|c|c|}
\hline & & $\begin{array}{l}\text { Unstandardiz } \\
\text { ed Residual }\end{array}$ \\
\hline \multicolumn{2}{|l|}{$\mathrm{N}$} & 5 \\
\hline \multirow[t]{2}{*}{ Normal Parameters a,b } & Mean & ,0000000 \\
\hline & Std. Deviation & 254,57258843 \\
\hline Most Extreme & Absolute & ,300 \\
\hline \multirow{2}{*}{ Differences } & Positive & ,300 \\
\hline & Negative &,- 225 \\
\hline Kolmogorov-Smirnov Z & &, 671 \\
\hline Asymp. Sig. (2-tailed) & & ,759 \\
\hline
\end{tabular}

Sumber: Data Primer diolah Agustus 2018

Pada tabel 4.5 di atas menunjukkan bahwa hasil pengujian normalitas data melalui uji Kolmogorov Smirnov ataupun Shapiro Wilk, nilai signifikan yang didapatkan pada masing-masing variabel nilainya lebih besar dari $\alpha=0,05$. Pada output data ini terlihat bahwa hasil uji normalitas menunjukkan level signifikansi lebih besar dari $\alpha(\alpha=0.05)$ yaitu $0,759>0,05$ yang berarti bahwa data terdistribusi dengan normal.

\section{Uji Heteroskedastisitas}

Keadaan heteroskedasitas adalah lawan dari homoskedasitas. Uji Heteroskadestisitas bertujuan untuk menguji apakah dalam model regresi terjadi ketidaksamaan variance dan residual suatu pengamatan kepengamatan yang lain. Jika variance dan residual tetap, maka disebut homoskedestisitas dan jika berbeda disebut hetero skadestisitas. Model regresi yang baik adalah tidak adanya heteroskadestisitas.

Pengujian terhadap heterokedasitas dilakukan dengan melihat ada tidaknya pola tertentu pada grafik scaterplot. Jika membentuk pola tertentu, maka terdapat heterokedasitas. Jika titik-titiknya menyebar maka tidak terdapat hetero skedasitas. Scatterplot dapat dilihat pada Gambar berikut:

Tabel 4.6Hasil Pengujian Heteroskedastisitas

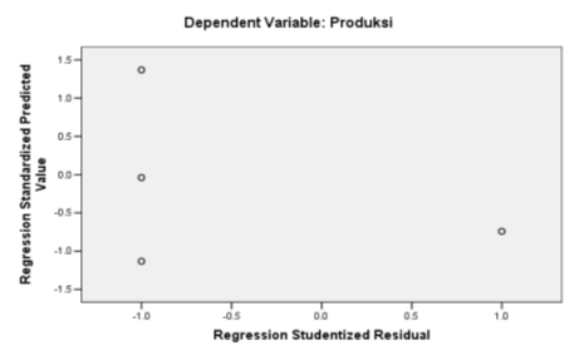


Sumber: Data Primer diolah Agustus 2018

Berdasarkan grafik di atas, terlihat bahwa titik-titik menyebar secara acak, tidak membentuk suatu pola tertentu yang jelas, serta tersebar diatas dan dibawah angka nol pada sumbu Y. Jadi, dapat disimpulkan bahwa model regresi dalam penelitian ini bebas dari heteroskedastisitas.

\section{Uji Multikolinieritas}

Pengujian multikolinearitas dilakukan untuk menjelaskan kemungkinan terdapatnya hubungan antara variabel independen yang satu dengan variabel independen yang lain.untuk mendeteksinya dalam penelitian ini dilakukan dengan melihat nilai variance Inflation Faktor $(V I F)$ untuk tiap-tiap variabel independen. Jika

korelasi antara variabel independen lemah (di bawah 0,10), maka dapat dikatakan bebas dari multikolinearitas. Dengan bantuan software SPSS, deteksi multikolinearitas menggunakan Variance Inflation Faktor (VIF) yang merupakan kebalikan dari toleransi. Hasil dari SPSS dapat dilihat pada tabel di bawah ini:

Tabel 4.7 Hasil Pengujian Multikolinieritas

\begin{tabular}{|l|l|l|}
\hline Variabel & VIF & Kesimpulan \\
\hline $\begin{array}{l}\text { Bahan } \\
\text { Baku }\end{array}$ & 1,290 & $\begin{array}{l}\text { Bebas } \\
\text { Multikolinieritas }\end{array}$ \\
\hline $\begin{array}{l}\text { Harga } \\
\text { Jual }\end{array}$ & 1,262 & $\begin{array}{l}\text { Bebas } \\
\text { Multikolinieritas }\end{array}$ \\
\hline $\begin{array}{l}\text { Jumlah } \\
\text { Mesin }\end{array}$ & 1,025 & $\begin{array}{l}\text { Bebas } \\
\text { Multikolinieritas }\end{array}$ \\
\hline
\end{tabular}

Sumber: Data Primer diolah Agustus 2018

Dari hasil perhitungan nilai VIF pada hasil analisis data diatas, diperoleh nilai VIF untuk bahan baku sebesar 1,290, variabel harga jual dengan nilai VIF sebesar 1,262, variable jumlah mesin dengan nilai VIF 1,025 Angka tersebut menunjukkan bahwa nilai VIF berada dibawah angka 10 artinya dalam penelitian ini telah bebas dari multikolinieritas dan data ini layak untuk diuji.

\section{Uji Autokorelasi}

Uji Autokorelasi bertujuan untuk menguji apakah dalam sebuah model regresi linier ada korelasi antara kesalahan pengganggu (error) pada periode $t$ dengan kesalahan pengganggu pada periode sebelumnya, jika ada berarti terdapat Autokorelasi. Pada penelitian ini mengetahui adanya autokorelasi dengan menggunakan

Durbin Watson Test, yaitu:

1. jika Durbin Watson(DW) dibawah -2 berarti terdapat autokorelasi positif 
2. jika Durbin Watson (DW) diantara -2 sampai 2 berarti tidak ada autokorelasi

3. jika Durbin Watson (DW) diatas +2 berarti ada autokorelasi negatif

Selanjutnya untuk memudahkan dalam analisis data pada pembahasan penelitian ini, maka dalam pengolahan dari data analisis digunakan paket program komputer yaitu program SPSS. Hasil uji Durbin Watson dengan menggunakan SPSS dapat dilihat pada tabel di bawah ini:

Tabel 4.8Hasil Pengujian Autokorelasi

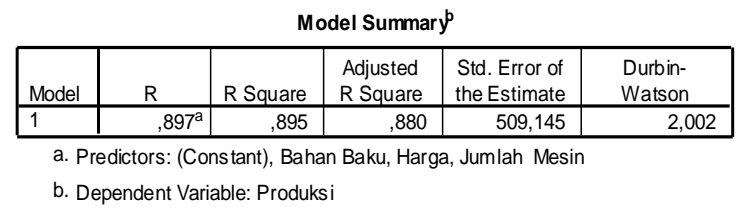

Sumber: Data Primer diolah Agustus 2018

Berdasarkan hasil uji DurbinWatson pada tabel diatas diperoleh nilai DW

untuk kedua variabel independen adalah sebesar 2.002. Ini menunjukkan bahwa nilai DW berada diantara -2 sampai 2 yang artinya apabila nilai DW berada di sekitar -2 sampai 2 tidak terjadi autokorelasi, sehingga dapat disimpulkan tidak terdapat autokorelasi dalam model penelitian ini.

\section{Hasil Analisis Korelasi dan Regresi Berganda}

Metode statistik yang digunakan untuk menguji hipotesis adalah regresi berganda dengan bantuan perangkat lunak SPSS for Windows versi 17.00. Metode yang menghubungkan satu variabel dependen dengan beberapa variabel independen, sesuai dengan hipotesis yang diuji dalam penelitian.

Tingkat hubungan atau korelasi antara variabel terikat $(\mathrm{Y})$ dan variabel bebas $(\mathrm{X} 1, \mathrm{X} 2$, dan $\mathrm{X} 3)$ dapat dilihat pada tabel berikut:

\section{Tabel 4.9Hasil Pengujian Korelasi}

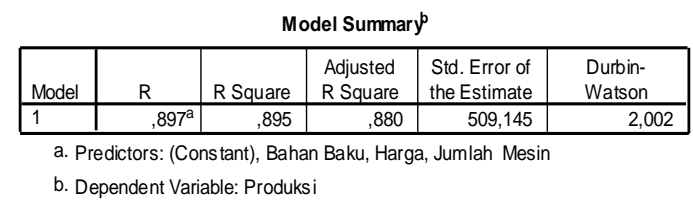

Sumber: Data Primer diolah Agustus 2018

Berdasarkan hasil penghitungan pada tabel 4.9 dapat diketahui bahwa korelasi yang terjadi antara variabel berbas terhadap variabel terikat menunjukkan nilai korelasi $\mathrm{R}^{2}=0,895$, hal ini mengindikasikan bahwa variabel Bahan Baku (X1), Harga (X2) dan Jumlah Mesin (X3) mempunyai korelasi terhadap variabel Produksi (Y). Angka korelasi tersebut mengandung arti bahwa korelasi yang terjadi adalah korelasi positif atau searah serta korelasi yang kuat karena nilainya mendekati angka 1 .

Hasil pengujian pada tabel 4.9 di atas juga menunjukkan nilai koefisien determinasi sebesar 0,880. Hal ini berarti 88\% variabel Produksi (Y) dapat dijelaskan oleh variabel Bahan Baku (X1), Harga (X2) dan Jumlah Mesin (X3). Dengan kata lain sumbangan efektif 
(kontribusi) variabel independen terhadap variasi (perubahan) jumlah produksi $(\mathrm{Y})$ adalah sebesar $88 \%$ dan sisanya $12 \%$ dijelaskan oleh faktor lain yang tidak dimasukkan dalam penelitian ini.

Selanjutnya adalah mengetahui persamaan regresi linier yang dihasilkan dengan persamaan regresi berganda sebagai berikut:

$\mathrm{Y}=\alpha+\beta 1 \times 1+\beta 2 \times 2+\beta 3 \times 3+\varepsilon$

$\mathrm{Y}=$ Produksi fiber (variabel tak bebas/ terikat)

$\mathrm{X} 1$ = Bahan baku (variabel bebas)

$\mathrm{X} 2$ = Harga jual (variabel bebas)

X3 = Jumlah Mesin (variabel bebas) $\mathrm{a}=$ Konstanta

$\mathrm{b}=$ Koefisien Regresi atau nilai Parameter

e $=$ Variabel Error

Hasil persamaan regresi ini dipakai untuk menguji hipotesis dengan menggunakan $\mathrm{t}$ test dengan tingkat keyakinan 97\%. Jika hasil regresi p-value $>0.05$ Ho diterima berarti Ha ditolak, sebaliknya jika $p$-value $<0.05$ Ho ditolak atau Ha diterima.

Tabel berikut ini akan memperlihatkan hasil dari perhitungan untuk analisis regresi linier berganda sebagai berikut :

\section{Tabel 4.10Hasil Pengujian Regresi Berganda}

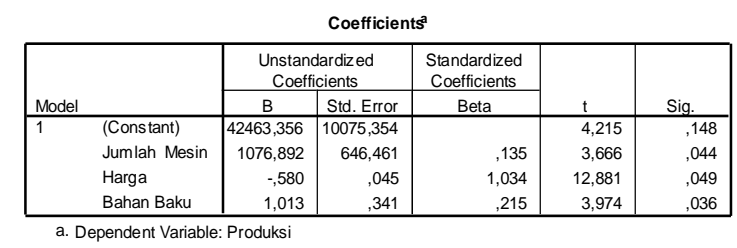

Sumber: Data Primer diolah Agustus 2018

Berdasarkan tabel di atas dapat dijelaskan bahwa variabel X1, X2, dan X3 signifikan, karena nilai sig lebih kecil dari 0,05 . Pada tabel di atas dapat dibuat sebuah persamaan regresi linier sederhana sebagai berikut:

\section{$Y=42463,356+1,013 X 1-0,580$ $\mathrm{X} 2+1076,892$ X3}

Dari persamaan regresi tersebut dapat dilihat bagaimana pengaruh variabel Jumlah mesin, harga jual dan bahan baku terhadap produksi hasil laut PT. Starfood International Lamongan. Pengaruh positif menunjukkan bahwa perubahan variabel independen akan searah dengan perubahan jumlah produksi. Dari persamaan regresi linier sederhana tersebut menunjukkan bahwa variabel Jumlah mesin berpengaruh positif artinya setiap perubahan pada variabel bebas akan memberikan pengaruh searah terhadap Hasil Produksi. Sedangkan Harga Jual berpengaruh negatif, artinya setiap perubahan pada variabel bebas akam memberikan pengaruh yang berlawanan arah. Demikian halnya dengan variabel Jumlah Bahan Baku, berpengaruh positif terhadap jumlah produksi, artinya setiap perubahan pada variabel bebas akan memberikan pengaruh searah terhadap Hasil Produksi. Adapun makna dari persamaan regresi linier tersebut adalah sebagai berikut:

a. Konstanta $=42463,356$. Apabila variabel Bahan Baku (X1), variabel Harga (X2), dan variabel Jumlah Mesin (X3) tidak ada peningkatan, maka tingkat Produksi (Y) adalah sebesar 42463,356.

b. $b=1,013$. Apabila variabel Bahan Baku (X1) ditingkatkan sebesar 1 satuan, maka akan meningkatkan Produksi (Y) sebesar 1,013 satuan. Asumsi yang digunakan adalah bahwa 
variabel lain yaitu Harga (X2) dan Jumlah Mesin (X3) adalah konstan.

c. $c=-0,580$. Apabila variabel Harga (X1) ditingkatkan sebesar 1 satuan, maka akan menurunkan Produksi (Y) sebesar 0,580 satuan. Asumsi yang digunakan adalah bahwa variabel lain yaitu Bahan Baku (X1) dan Jumlah Mesin (X3) adalah konstan.

d. $d=1076,892$. Apabila variabel Jumlah Mesin (X3) ditingkatkan sebesar 1 satuan, maka akan menurunkan Produksi (Y) sebesar 1076,892 satuan. Asumsi yang digunakan adalah bahwa variabel lain yaitu Bahan Baku (X1) dan Harga (X2) adalah konstan.

\section{Hasil Pengujian Hipotesis}

\section{Hasil Pengujian Hipotesis I}

Untuk melakukan pengujian apakah variabel independent secara simultan (bersama-sama) mempunyai pengaruh terhadap variabel dependent atau tidak berpengaruh maka digunakan uji $\mathrm{F}$ (Ftest) yaitu dengan cara membandingkan $\mathrm{F}_{\text {hitung }}$ dengan $\mathrm{F}_{\text {tabel. }}$ Kriteria pengujiannya adalah jika $\mathrm{F}_{\text {hitung }}>\mathrm{F}_{\text {tabel }}$ maka $\mathrm{H}_{\mathrm{o}}$ ditolak dan $\mathrm{H}_{\mathrm{a}}$ diterima, sedangkan apabila $F_{\text {hitung }}<\mathrm{F}_{\text {tabel }}$ maka $\mathrm{H}_{\mathrm{o}}$ diterima dan $\mathrm{H}_{\mathrm{a}}$ ditolak.

Hasil pengujian hipotesis pengaruh variabel Bahan Baku (X1), Harga (X2) dan Jumlah Mesin (X3) secara simultan terhadap Jumlah Produksi (Y) dapat dilihat pada tabel berikut:

Tabel 4.11Hasil Pengujian Regresi Berganda Pada Uji Simultan

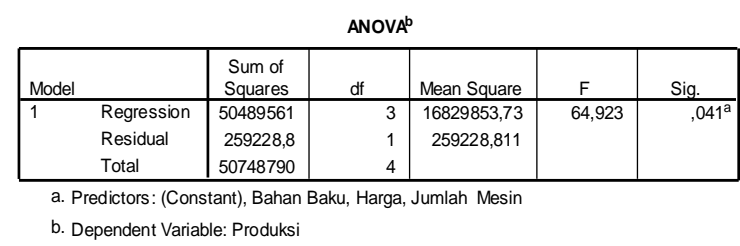

Sumber: Data Primer diolah Agustus 2018

Berdasasarkan hasil pengujian tingkat signifikansi pengaruh pada tabel 4.11 di atas menunjukkan bahwa pengaruh dari variabel independen Bahan Baku (X1), Harga (X2) dan Jumlah Mesin (X3) secara bersama-sama adalah signifikan terhadap variabel Produksi (Y). Hal ini ditunjukkan dengan nilai $F_{\text {hitung }}$ lebih besar dari $F_{\text {tabel. }}$ Nilai $F_{\text {hitung yang }}$ didapatkan adalah sebesar 64,923 sedangkan nilai $\mathrm{F}_{\text {tabel }}$ dapat dilihat pada tabel Uji F.

Nilai $F_{\text {tabel }}$ merupakan sebuah nilai statistik $\mathrm{F}$ dengan derajat bebas $\mathrm{k}-1$ dan $\mathrm{n}-\mathrm{k}$. Dimana $\mathrm{k}=$ jumlah variabel yang diteliti yaitu 3 variabel.

$\mathrm{n} \quad=$ lama waktu yang diteliti yaitu selama 8 tahun

Ftabel $=(\mathrm{k}-1):(\mathrm{n}-\mathrm{k})$

$$
\begin{aligned}
& =(3-1):(5-3) \\
& =2: 2
\end{aligned}
$$

Setelah dilihat pada Tabel F dengan pembilang (N1) sebesar 2 dan penyebut (N2) sebesar 2 maka diperoleh $F_{\text {tabel }}$ sebesar 19,00.

Karena $F_{\text {hitung }}>F_{\text {tabel }}(64,923>$ 19,00). Selain itu juga dapat dilihat pada nilai signifikansi yang dihasilnya yaitu 0,000 yang nilainya kurang dari $\alpha(0,000$ $<0,05)$. Hal ini berarti bahwa variabel Bahan Baku (X1), Harga (X2) dan Jumlah Mesin (X3) berpengaruh signifikan terhadap Jumlah Produksi (Y) PT. Starfood International Lamongan. Dengan demikian dapat dikatakan bahwa hipotesis I telah teruji atau terbukti.

\section{Hasil Pengujian Hipotesis II}


Uji t digunakan untuk mengetahui pengaruh masing-masing variabel independent, yaitu Bahan Baku (X1), Harga (X2) dan Jumlah Mesin (X3)berpengaruh signifikan terhadap Produksi (Y) PT. Starfood International Lamongan dengan cara membandingkan nilai $t_{\text {hitung dengan }} t_{\text {tabel }}$, dengan derajat

Tabel 4.12Hasil Pengujian Regres Berganda

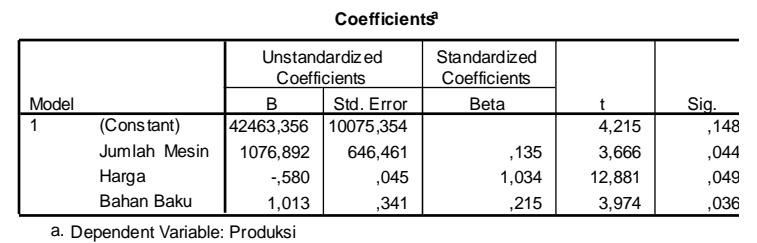

Sumber: Data Primer diolah Agustus 2018

Berdasarkan hasil pengujian pada tabel 4.35 di atas dapat digambarkan hasil uji masing-masing variabel sebagai berikut:

a. Variabel Bahan Baku (X1) mempunyai nilai thitung sebesar 3,666 dengan probabilitas 0,044 . Karena $t_{\text {hitung }}>t_{\text {tabel }}$ $(3,666>2,776)$ serta tingkat signifikansi $<\alpha(0,044<0,05)$, maka secara parsial variabel Bahan Baku (X1) berpengaruh secara signifikan terhadap variabel Produksi (Y).

b. Variabel Harga (X2) mempunyai nilai $t_{\text {hitung sebesar 12,881 dengan }}$ probabilitas 0,000 . Karena $t_{\text {hitung }}>t_{\text {tabel }}$ $(12,881>2,776)$ serta tingkat signifikansi $<\alpha(0,049<0,05)$, maka secara parsial variabel Harga (X2) berpengaruh secara signifikan terhadap variabel Produksi (Y).

c. Variabel Jumlah Mesin (X3) mempunyai nilai $t_{\text {hitung }}$ sebesar 3,974 dengan probabilitas 0,000. Karena $t_{\text {hitung }}>t_{\text {tabel }}(3,974>2,776)$ serta tingkat signifikansi $<\alpha(0,036<0,05)$, maka secara parsial variabel Jumlah Mesin (X3) berpengaruh secara kebebasan (degree of freedom) sebesar 95\% $(\alpha=5 \%)$. Nilai $t_{\text {tabel }}$ dilihat pada tabel dengan nilai df $4(\mathrm{n}-(\mathrm{k}+1)=5-$ $(3+1)=4)$ yaitu sebesar 2,776. Hasil pengujian secara parsial dapat dilihat pada tabel berikut:

signifikan terhadap variabel Produksi (Y).

Dari hasil analisis di atas dapat dinyatakan bahwa masing-masing variabel independen Bahan Baku (X1), Harga (X2) dan Jumlah Mesin (X3)berpengaruh signifikan terhadap Produksi (Y) pada PT. Starfood International Lamongan.

Selanjutnya mengetahui variabel independen yang berpengaruh paling dominan terhadap variabel dependen dapat dilihat pada masing-masing koefisien regresi ( $\beta$ ) masing-masing variabel pada persamaan regresi. Berdasarkan hasil analisis dari masingmasing variabel menunjukkan bahwa nilai koefisien regresi $\left(\beta_{1}\right)$ pada variabel Bahan Baku $=0,135$, koefisien regresi $\left(\beta_{2}\right)$ variabel Harga $=1,034$ dan koefisien regresi $\left(\beta_{1}\right)$ pada variabel Jumlah Mesin = 0,215. Dari hasil tersebut dapat dinyatakan bahwa variabel yang mempunyai pengaruh dominan adalah variabel Harga, karena nilai koefisien yang paling besar diantara variabel yang lain. Dengan demikian dapat dikatakan bahwa hipotesis 2 telah terbukti atau teruji.

\section{PEMBAHASAN}

Setiap perusahaan memerlukan suatu manajemen yang berkaitan dengan usaha-usaha untuk mencapai tujuan tertentu bagi prusahaan tersebut. Kebutuhan akan manajemen yang baik diperlukan agar dapat memberikan pelayanan kepada publik atau masyarakat 
Humanis Vol 11 No 2

dengan baik pula. Berhasil atau tidaknya suatu perusahaan dalam mencapai tujuannya tergantung dari keberhasilan daripada individu dalam perusahaan itu sendiri dalam menjalankan tugas mereka. Berbagai macam hambatan pasti akan ditemui oleh perusahaan untuk bisa bekerja dengan baik sehingga kinerja mereka dapat diterima dengan baik oleh lembaga dan masyarakat yang memerlukan.

Dalam menjalankan proses produksi tidak dapat dijalankan dengan sendirinya, tetapi dilakukan secara bersamasama dengan bantuan orang lain sehingga diperlukan kegiatan manajemen. Kegiatan manajemen ini diperlukan untuk mengatur serta mengkombinasikan faktor-faktor produksi untuk meningkatkan kegunaan dari barang dan jasa secara efektif dan efisien dengan memanfaatkan keterampilan skill yang dimiliki oleh manajernya dalam memahami faktorfaktor yang mempengaruhi produksi.

Berdasarkan hasil penelitian yang dilakukan pada PT. Starfood International menunjukkan bahwa kegiatan produksi sangat dipengaruhi oleh jumlah Bahan Baku, Harga Jual dan Jumlah mesin yang dimiliki perusahaan.

Hal tersebut sesuai dengan pendapat Assauri (2004) yang menyatakan bahawa kegiatan produksi juga erat kaitannya dengan faktor-faktor produksi, sehingga bagi seorang pimpinan sebagai pengambil keputusan harus diperhatikan hal ini dengan serius, dimana faktor-faktor inilah nantinya yang diolah dalam suatu proses untuk menambah kegunaan suatu barang atau jasa. Adapun faktor-faktor produksi tersebut adalah tenaga kerja, modal, skill, bahan baku serta peralatan dan mesin.

Bahan baku merupakan faktor yang mempunyai peran penting dalam menunjang kelancaran proses produksi dan pencapaian kemampuan ataupun rencana produksi yang telah ditetapkan. Oleh karena itu perusahaan perlu membuat kebijaksanaan yang tepat untuk persediaan bahan baku, hal ini bertujuan agar proses produksi tidak terganggu, maka perlu bagi suatu perusahaan untuk memperkirakan kebutuhan bahan bakunya secara cermat. Juga melakukan pengawasan yang baik guna mengantisipasi resiko kekurangan bahan baku.

Faktor yang mempengaruhi produksi yang lainnya adalah Harga Jual. Menurut Kotler (2001: 439), harga adalah jangka waktu nilai yang ditukar oleh konsumen untuk review memperoleh suatu produk, atau sejumlah uang yang dibebankan untuk review konsumen guna get barang atau jasa. Harga Sangat berpengaruh pada citra produk dan kelangsungan produk dipasaran. jika harga suatu produk terlalu murah atau terlalu mahal, hal tersebut dapat berpengaruh buruk untuk review suatu produk. Oleh karena itu, hearts menetapkan harga suatu produk perlu adanya penetapan tujuan dan mengembangkan suatu struktur penetapan harga yang tepat (Putong, 2013).

Selain bahan baku dan harga yang perlu diperhatikan adalah peralatan produksi atau mesin yang akan digunakan untuk pelaksanaan proses produksi dalam perusahaan mempunyai peran yang sangat besar. Peralatan ini berpengaruh terhadap produk, efisiensi produksi didalam perusahaan yang bersangkutan. Kekeliruan dalam pembelian pemilihan peralatan produksi yang akan digunakan dalam pelaksanaan proses produksi akan berakibat fatal bagi perusahaan yang menggunakannya. Oleh karena itu perusahaan yang bersangkutan harus benar-benar mengetahui tentang spesifikasi dari peralatan produksi yang hendak dipergunakannya. Seberapa pentingnya peralatan/mesin dalam kegiatan produksi di suatu perusahaan disampaikan oleh Assauri (2004) yang menyatakan bahwa Peralatan adalah suatu 
kekuatan atau tenaga yang dipergunakan untuk membantu manusia dalam mengerjakan produk atau bagian produkproduk tertentu.

Dengan demikian dapat disimpulkan bahwa untuk meningkatkan nilai produksi pada PT. Starfood International Lamongan perlu diperhatikan faktor-faktor antara lain Bahan Baku, Harga Jual dan Jumlah Mesin.

\section{SIMPULAN DAN SARAN}

\section{Simpulan}

Berdasarkan hasil penelitian, maka dapat ditarik kesimpulan sebagai berikut:

1. Faktor bahan baku, harga, dan jumlah mesin secara simultan atau secara bersama-sama mempunyai pengaruh yang signifikan terhadap hasil produksi, hal ini didasarkan dari hasil Uji-F yang menyatakan Fhitung lebih besar dari Ftabel pada taraf level signifikan 0,05 yakni Fhitung $(65.923)>$ Ftabel $(19,00)$.

2. Variabel Bahan Baku (X1) yang mempunyai pengaruh terhadap hasil produksi,

dimana thitung lebih besar dari ttabel yaitu 3,666 > 2,776 sehingga dapat disimpulkan semakin banyak bahan baku bertambah maka hasil produksi juga akan meningkat.

3. Variabel Harga (X2) yang mempunyai pengaruh terhadap hasil produksi, dimana thitung lebih besar dari ttabel yaitu $12,881>2,776$ akan tetapi pengaruhnya berlawanan arah sehingga dapat disimpulkan semakin tinggi harga jual maka hasil produksi akan menurun.

4. Variabel Jumlah Mesin (X3) yang mempunyai pengaruh terhadap hasil produksi,

dimana thitung lebih besar dari ttabel yaitu 3,974 $>2,776$ sehingga dapat disimpulkan semakin banyak jumlah
Humanis Vol 11 No 2

mesin maka hasil produksi juga akan meningkat.

5. Berdasarkan perhitungan nilai koefesien determinasi $\left(\mathrm{R}^{2}\right)$ sebesar 0,895 . Hal ini menunjukkan bahwa bahan baku, harga, dan jumlah mesin secara simultan memberikan pengaruh sebesar $89,5 \%$ terhadap produksi hasil laut pada PT. Starfood International Lamongan. Sisanya $10,5 \%$ dipengaruhi oleh faktor lain yang tidak diteliti.

\section{Saran}

1. Agar produksi hasil laut dapat memenuhi target yang telah ditetapkan perusahaan, maka pihak perusahaan, maka pihak perusahaan perlu membuat perencanaan bahan baku yang lebih baik serta membuat target yang jelas terhadap pemenuhan kebutuhan bahan baku dari pihak lain, sehingga tidak terjadi kekurangan bahan baku.

2. Agar peralatan-peralatan dapat bekerja secara optimal, perusahaan hendaknya lebih memperhatikan kondisi peralatan serta kegiatan pemeliharaan perlu dilakukan dengan sebaik-baiknya.

3. Perusahaan hendaknya lebih memperhatikan penentuan harga jual hasil produksi laut sehingga tidak terjadi penurunan jumlah produksi karena turunnya jumlah permintaan pasar yang disebabkan harga yang tidak sesuai.

4. Penelitian ini masih mempunyai banyak keterbatasan, baik dari jumlah sampel penelitian maupun variabel penelitian, karena faktor-faktor yang menentukan dan mempengaruhi jumlah produksi bukan hanya bahan baku.

\section{DAFTAR PUSTAKA}

Al-madhahachi Hayder, Mina Gao. Key factors affecting the water production in a thermoelectric 
distillation System. Energy

Conversion and Management 165; (2018) 459-464

Assauri, Sofjan, 2004, Manajemen Produksi dan Operasi, Edisi Revisi, Fakultas

Ekonomi Universitas Indonesia, Jakarta.

Bea FX, Haas J. Strategisches Management. Stuttgart: Lucius \& Lucius Verlagsgesellschaft; 2009. p. 29.

Becker T. Prozesse in Produktion und Supply Chain optimieren. 2. Auflage. Berlin: Springer-Verlag; 2008. p. 56.

CIRP. Dictionary of Production Engineering. Vol. 3. Berlin: Springer- Verlag; 2004. p. 18.

Dombrowski U, Intra C, Zahn T, Krenkel P. Manufacturing Strategy: A Neglected Success Factor for Improving Competitiveness. 48th CIRP Conference on Manufacturing Systems; 2015. p. 9-14.

Friedli T. Technologiemanagement: Modelle zur Sicherung der Wettbewerbsfähigkeit. Berlin: Springer-Verlag; 2006. p. 51.

Grassetti Francesca, Mammana Cristiana, Michetti Elisabetta. Substitutability between production factors and growth. An analysis using VES production functions. Chaos, Solitons and Fractals 113; 2018. P. 53-62.

Hungenberg H, Wulf T. Grundlagen der Unternehmensführung. Zweite, aktualisierte Auflage. Berlin: Springer Verlag; 2006. p. 147-149.

Jodlbauer $H$. Produktionsoptimierung: Wertschaffende sowie kundenorientierte Planung und Steuerung. Berlin: Springer; 2008. p. 21- 40 .

Kolus Ahmet, Wells Richard, Patrick Neumann. Production quality and human factors engineering: A systematic review and theoretical
Humanis Vol 11 No 2

framework. Applied Ergonomics 73; 2018. P. 55-89.

Lakatos G, Balogh D, Farkas A, Ördög V, Nagy T.P, Bíró $T$, Maróti G. Factors influencing algal photobiohydrogen production in algal-bacterial cocultures. Algal Research 28; (2017) 161-171.

Li Yanli, Li Lijun. A Preliminary Study of Environment Capacity Production Factor. Energy Procedia 16; (2012) $296-301$

Liker JK. The Toyota Way: 14 Management Principles from the World's Greatest Manufacturer. McGraw-Hill; 2004. p. 32/33.

production: A systematic review of factors affecting the production, carcass and Macías S.D, Maggi B.L, DelaNuez M.A, Paredes P.J. Guinea pig for meat meat quality. 2018, doi:10.1016/j.meatsci.2018.05.004.

Northey S, Cristina M.L, Haque N, Gavin M. Mudd, Yellishetty M. Production weighted water use impact characterisation factors for the global mining industry. Journal of Cleaner Production 184; (2018) 788-797.

Nyhuis P, Wiendahl H.-P. Logistische Kennlinien: Grundlagen, Werkzeuge und Anwendungen. 3. Auflage. Berlin: Springer-Verlag; 2012. p. 17-27.

Piller FT. Mass Customization: Ein wettbewerbsstrategisches Konzept im Informationszeitalter. Wiesbaden: Deutscher UniversitätsVerlag; 2006. p.114/115.

Porter ME. Competitive Advantage: Creating and Sustaining Superior Performance. New York: The Free Press; 1998. p. 11-17.

Rufaidah Erlina (2015), Ilmu Ekonomi, Cetakan Pertama, Graha Ilmu, Yogyakarta.

Schuh G, Behr M, Brecher C, BührigPolaczek A, Michaeli W, Arnoscht 
J, Bohl A, Buchbinder D, Bültmann J, Diatlov A, Elgeti S, Herfs W, Hinke C, Karlberger A, Kupke D, Lenders M, Nußbaum C, Probst M, Queudeville Y, Quick J, Schleifenbaum H, Vorspel-Rüter M, Windeck C. Individualised Production. In: Brecher C, editor. Integrative Production Technology for High-Wage Countries. Berlin: Springer-Verlag; 2012. p. 108-111.

Sadono Sukirno, Mikroekonomi Teori Pengantar, (Jakara: PT RajaGrafindo Persada, 2009), h. 75 Sumar'in, Ekonomi Islam : Sebuah Pendekatan Ekonomi Mikro Perspektif Islam, (Yogyakarta: Graha Ilmu, 2013), h.105

Teece DJ, Pisano G, Shuen A. Dynamic Capabilities and Strategic Management. Volume 18. Number 7. Strategic Management Journal; 1997. p. 509-533.

Töpfer A. Betriebswirtschaftslehre: Anwendungs- und prozessorientierte Grundlagen. 2. Auflage. Berlin: Springer; 2007. p. 792.
Humanis Vol 11 No 2

Wiendahl H-P, Nyhuis P, Fischer A, Grabe D. Controlling in Lieferketten. In: Schuh G editors. Produktionsplanung und -steuerung: Grundlagen,Gestaltung und Konzepte. Berlin: Springer-Verlag; 2006. p. 467.

Xiong L, Wang $\mathrm{F}$, Cheng $\mathrm{B}$, Yu C. Identifying factors influencing the forestry production efficiency in Northwest China. Resources, Conservation \& Recycling 130; (2018) 12-19.

Yoopi Abimanyu, Ekonomi Manajerial, edisi ke 2 (Bogor: Ghalia Indonesia, 2012), h. 12-13.

Zhao J,Tang Dazhen, HaoXu, Lv Yumin, Tao shu. High production indexes and the key factors in coalbed methane production: A case in the Hancheng block, southeastern Ordos Basin, China. J. Petrol. Sci. Eng.

(2015), http://dx.doi.org/10.1016/j.petrol.20 $\underline{15.03 .005}$

Zäpfel G. Strategisches ProduktionsManagement. München: Oldenbourg Wissenschaftsverlag; 2000. p. 30. 